\title{
Potassium fertilization in the cultivation of colored cotton irrigated with saline water
}

\author{
André A. R. da Silva ${ }^{1}$, Geovani S. de Lima ${ }^{1}$, Carlos A. V. de Azevedo ${ }^{1}$, \\ Lauriane A. dos A. Soares ${ }^{1}$, Hans R. Gheyi ${ }^{2} \&$ Raucha C. de Oliveira ${ }^{1}$ \\ ${ }^{1}$ Universidade Federal de Campina Grande/Centro de Tecnologia e Recursos Naturais/Unidade Acadêmica de Engenharia Agrícola. Campina \\ Grande, PB. E-mail: andrealisson_cgpb@hotmail.com; geovanisoareslima@gmail.com (Corresponding author); cvieiradeazevedo@gmail.com; \\ laurispo.agronomia@gmail.com; rauchaoliveira@gmail.com \\ ${ }^{2}$ Universidade Federal do Recôncavo da Bahia/Centro de Ciências Agrárias, Ambientais e Biológicas/Núcleo de Engenharia de Água e Solo. Cruz \\ das Almas, BA. E-mail: hans@pq.cnpq.br
}

\section{Key words:}

Gossypium hirsutum L.

'BRS Topázio'

salt stress

potassium

\begin{abstract}
A B S T R A C T
The objective of this study was to evaluate growth, flowering and production components of the cotton cv. 'BRS Topázio' irrigated with water of different salinity levels and potassium (K) doses in the soil. The research was conducted in a greenhouse. The experiment was set in a randomized complete block design with four replicates, in $4 \times 4$ factorial arrangement with 4 levels of irrigation water salinity $\left(1.5,3.0,4.5\right.$ and $\left.6.0 \mathrm{dS} \mathrm{m}^{-1}\right)$ and four $\mathrm{K}$ doses $(50,75$, 100 and $125 \%$ of the recommendation); the dose of $100 \%$ corresponded to $150 \mathrm{mg} \mathrm{K}_{2} \mathrm{O} \mathrm{kg}^{-1}$ of soil. Irrigation water salinity reduced stem diameter, plant height, number of leaves and leaf area of the cotton cv. 'BRS Topázio'. Leaf area at 53 DAS was the most affected variable. The highest $\mathrm{K}$ dose associated with increased salinity of the irrigation water caused a more deleterious effect on the number of leaves and leaf area at 108 DAS. Progressive increases in irrigation water salinity proportionally increased flower abortion rate and, consequently, reduced the total number of bolls and seed weight of cotton.
\end{abstract}

\section{Palavras-chave:}

Gossypium hirsutum L.

BRS Topázio

estresse salino

potássio

\section{Adubação potássica no cultivo do algodoeiro de fibra colorida irrigado com águas salinas}

\section{R E S U M O}

Objetivou-se neste trabalho avaliar crescimento, floração e os componentes de produção do algodoeiro cv. BRS Topázio em função da irrigação com águas de diferentes níveis de salinidade e doses de potássio no solo. A pesquisa foi conduzida em casa de vegetação. $\mathrm{O}$ delineamento experimental utilizado foi o de blocos casualizados em arranjo fatorial $4 \times 4$, com três repetições cujos tratamentos consistiram de quatro níveis de condutividade elétrica da água de irrigação $\left(1,5 ; 3,0 ; 4,5\right.$ e $\left.6,0 \mathrm{dS} \mathrm{m}^{-1}\right)$ e quatro doses de potássio $(50 ; 75 ; 100$ e $125 \%$ da recomendação), sendo a dose de $100 \%$ correspondente a $150 \mathrm{mg} \mathrm{K}_{2} \mathrm{O} \mathrm{kg}^{-1}$ de solo. A salinidade da água de irrigação reduziu o diâmetro de caule, altura de plantas, número de folhas e área foliar do algodoeiro, sendo a área foliar aos 53 dias após a semeadura (DAS) a variável mais afetada. As maiores doses de potássio associadas ao aumento da salinidade da água de irrigação proporcionaram um efeito depressivo no número de folhas e na área foliar aos 108 DAS. Aumentos progressivos da salinidade da água de irrigação elevaram, de forma proporcional, a taxa de abortamento de flores e, consequentemente, reduziram o número de capulhos total e a massa de algodão em caroço. 


\section{INTRODUCTION}

Belonging to the Malvaceae family, herbaceous cotton (Gossypium hirsutum L.) is among the main crops cultivated in the world, because its fiber is one of the most used in the textile industry and has great applicability in various products, being inserted in the group of bioenergetic products (Alves et al., 2008). In Brazil, the production of colored cotton has stood out for its socioeconomic importance to maintain labor in rural areas and generate jobs, and for its great environmental appeal, since it eliminates the dyeing stage in the industry, which produces a large volume of residues, compromising the environment (Cardoso et al., 2010).

In the semiarid region of Northeast Brazil, especially in the state of Paraíba, one of the obstacles for cotton cultivation is the salinity of soil and/or irrigation water (Cavalcante et al., 2010). The presence of salts in excess in the water causes reduction in crop growth and production, due to the decrease of the osmotic potential of the soil solution and occurrence of ionic toxicity and nutritional imbalances (Khan \& Panda, 2008).

Although cotton is a crop tolerant to salt stress, with threshold salinity level of $5.1 \mathrm{dS} \mathrm{m}^{-1}$ in the irrigation water and $7.7 \mathrm{dS} \mathrm{m}^{-1}$ in the soil saturation extract (Ayers \& Westcot, 1999), variations in the tolerance level may occur depending on the genotype and other factors, such as type of cation/anion, concentration of salts, time of exposure to stress, phenological stage, edaphoclimatic conditions and fertilization management (Neves et al., 2008).

Potassium (K) fertilization can be considered as an alternative, which can minimize the deleterious effects caused by the high concentrations of salts in the water, because this macronutrient plays a key role in the osmotic regulation and promotes turgor maintenance in guard cells, which results in absorption of water by these cells and by adjacent cells and, consequently, generates more turgor and stomatal opening (Langer et al., 2004). Furthermore, it acts as osmoregulator, playing an essential role in water saving, cell turgor, carbohydrate transport and respiration (Shimazaki et al., 2007).

In this context, this study aimed to evaluate the effects of irrigation using water of different saline levels and $\mathrm{K}$ fertilization on the growth and production of the colored cotton cv. 'BRS Topázio’.

\section{MAterial ANd Methods}

The experiment was carried out from September 2016 to February 2017 in pots adapted as drainage lysimeters in a greenhouse at the Center of Technology and Natural Resources of the Federal University of Campina Grande (CTRN/UFCG), located in the municipality of Campina Grande, Paraíba, at local geographic coordinates $7^{\circ} 15^{\prime} 18^{\prime \prime} \mathrm{S}, 35^{\circ} 52^{\prime} 28^{\prime \prime} \mathrm{W}$ and mean altitude of $550 \mathrm{~m}$.

The experiment was set in randomized complete blocks, in a $4 \times 4$ factorial arrangement, with three replicates, and the treatments consisted of four levels of irrigation water electrical conductivity - ECw $\left(1.5 ; 3.0 ; 4.5\right.$ and $\left.6.0 \mathrm{dS} \mathrm{m}^{-1}\right)$ and four $\mathrm{K}$ doses - KD (50, 75, 100 and 125\%) recommended by Novais et al. (1991), and the dose of $100 \%$ corresponded to $150 \mathrm{mg} \mathrm{K}_{2} \mathrm{O} \mathrm{kg}^{-1}$ of soil. The experiment used drainage lysimeters with capacity for $20 \mathrm{~L}$, perforated at the bottom to allow drainage and connected to a transparent drain with diameter of $4 \mathrm{~mm}$. The tip of the drain inside the lysimeter was involved in a nonwoven geotextile (Bidim OP 30) to avoid obstruction with soil material. A plastic bottle was placed below each drain to collect the drained water, in order to estimate water consumption by the plants.

Each lysimeter received a $0.5-\mathrm{kg}$ layer of crushed stone followed by $22 \mathrm{~kg}$ of a eutrophic Regolithic Neosol with sandy loam texture $(0-0.20 \mathrm{~m})$, from the municipality of Esperança, $\mathrm{PB}$, whose chemical and physical-hydraulic attributes were determined according to Claessen (1997): $\mathrm{Ca}^{2+}, \mathrm{Mg}^{2+}, \mathrm{Na}^{+}, \mathrm{K}^{+}$, $\mathrm{H}^{+}, \mathrm{Al}^{3+}=3.49 ; 2.99 ; 0.17 ; 0.21 ; 5.81$ and $0 \mathrm{cmol}_{\mathrm{c}} \mathrm{kg}^{-1}$, respectively; $\mathrm{CEC}=12.67 \mathrm{cmol}_{\mathrm{c}} \mathrm{kg}^{-1}$; organic matter $=1.83 \mathrm{dag} \mathrm{kg}{ }^{-1} ; \mathrm{P}=18.2$ $\mathrm{mg} \mathrm{kg}^{-1} ; \mathrm{pH}$ in water $(1: 2.5)=5.63$; Saturation extract electrical conductivity $\left(\mathrm{dS} \mathrm{m}^{-1}\right)=0.61$; $\mathrm{SAR}\left(\mathrm{mmol} \mathrm{L}^{-1}\right)^{1 / 2}=1.46$; sand, silt and clay $=572.3,100.8$ and $326.9 \mathrm{~g} \mathrm{~kg}^{-1}$, respectively; moisture at 33.42 and $1519.5 \mathrm{kPa}=12.68$ and $4.98 \mathrm{dag} \mathrm{kg}^{-1}$, respectively.

This study evaluated the colored cotton cultivar 'BRS Topázio', for having high percentage of fiber (43.5\%), high uniformity $(85.2 \%)$ and high resistance $\left(31.9 \mathrm{gf} \mathrm{tex}^{-1}\right)$, promoting excellent characteristics, comparable to cultivars with white fiber and superior to the other cultivars with colored fiber. The mean yield achieved by the cultivar 'BRS Topázio' is $2,825 \mathrm{~kg} \mathrm{ha}^{-1}$ under irrigated cultivation (EMBRAPA, 2011).

Irrigation water was prepared using commercial iodinefree sodium chloride $(\mathrm{NaCl})$, adjusting the concentration of the public-supply water and considering the ratio between ECw and the concentration of salts $\left(10^{*} \mathrm{mmol}_{c} \mathrm{~L}^{-1}=\mathrm{ECw} d \mathrm{dS}\right.$ $\mathrm{m}^{-1}$ ), according to Richards (1954). After preparation and ECw calibration, using a portable conductivity meter, the saline water was stored in $120-\mathrm{L}$ plastic recipients, properly protected to avoid evaporation.

Irrigations were manually performed and the applied irrigation depth was determined according to the water requirement of the plants, estimated through the water balance: applied volume minus the volume drained in the previous irrigation, plus a leaching fraction of 0.10 (Ayers \& Westcot, 1999). Before sowing, all lysimeters were taken to field capacity using water, according to the treatment. After sowing, irrigation was daily performed by applying, in each lysimeter, a water volume to maintain soil moisture close to field capacity. Seven seeds of the cotton cv. 'BRS Topázio' were planted in each lysimeter, at depth of $2 \mathrm{~cm}$ and equidistantly distributed. At 18 and 36 days after sowing (DAS), thinnings was performed to leave only one plant per lysimeter.

Basal fertilization with phosphorus was applied based on Novais et al. (1991), using $300 \mathrm{mg}$ of $\mathrm{P}_{2} \mathrm{O}_{5} \mathrm{~kg}^{-1}$ of soil in the form of monoammonium phosphate $\left(\mathrm{NH}_{4} \mathrm{H}_{2} \mathrm{PO}_{4}\right)$. Urea $\left(\mathrm{NH}_{2}-\mathrm{CO}-\right.$ $\mathrm{NH}_{2}$ ) was used as $\mathrm{N}$ source and potassium chloride $(\mathrm{KCl})$ as $\mathrm{K}$ source. The fertilizations with $\mathrm{N}$ and $\mathrm{K}$ were split; one third of each nutrient was applied at $15 \mathrm{DAS}$ and the rest in three equal applications, along with the saline water at 15-day intervals.

Foliar fertilizations with micronutrients were performed at $15,33,51,69$ and 87 DAS, using $1.5 \mathrm{~L}$ of solution containing $3.0 \mathrm{~g} \mathrm{~L}^{-1}$ of ubyfol (N-15\%; $\mathrm{P}_{2} \mathrm{O}_{5}-15 \%$; $\mathrm{K}_{2} \mathrm{O}-15 \%$; Ca- $1 \%$; Mg$1.4 \%$; S-2.7\%; Zn-0.5\%; B-0.05\%; Fe-0.5\%; Mn-0.05\%; Cu$0.5 \%$; Mo- $0.02 \%)$. The phytosanitary control was performed 
preventively with application of insecticides of the Carbonate and Neonicotinoid chemical groups, fungicide of the Triazole chemical group, and acaricide of the Abamectin chemical group.

The effects of the treatments on the crop were evaluated through the growth variables: stem diameter (SD), plant height $(\mathrm{PH})$, number of leaves (NL) and leaf area (LA) at 53 and 108 DAS; flower abortion rate (FAR) was determined at 108 DAS and the production: number of bolls per plant and cotton seed weight at 136 DAS.

Plant height was measured as the distance between the base of the plant until the insertion of the apical meristem. Stem diameter was measured at $5 \mathrm{~cm}$ from the base of the plant. Leaf area was obtained by measuring the midrib length of all leaves, while leaf area per plant was determined by the sum of the leaf areas of all leaves, considering the methodology described by Grimes \& Carter (1969), according to Eq. 1:

$$
\mathrm{y}=\sum\left(0.4322 \mathrm{x}^{2.3002}\right)
$$

where:

y - total leaf area; and,

$\mathrm{x} \quad$ - midrib length of the cotton leaf.

Flower abortion rate was obtained through the relationship between the number of open flower buds and total number of flowers produced, in percentage. The bolls were harvested per plant always when they reached harvesting point; the total number of bolls was obtained through the count of all bolls produced per plant and cotton seed weight was determined for each plot.

The collected data were subjected to analysis of variance by F test; when significant, linear or quadratic regression analysis was performed using the program SISVAR (Ferreira, 2011). Variance and regression analyses were conducted at 0.05 and 0.01 probability levels.

\section{Results AND Discussion}

According to the summary of the analysis of variance (Table $1)$, there was a significant effect $(\mathrm{p}<0.01)$ of the water salinity levels (SL) on stem diameter (SD), plant height $(\mathrm{PH})$, number of leaves (NL) and leaf area (LA), at 53 and 108 DAS. The $\mathrm{K}$ doses $(\mathrm{KD})$ did not influence significantly $(\mathrm{p}>0.05)$ the studied variables in any of the evaluated periods. Regarding the interaction between factors (SL x KD), significant effect (p $<0.01$ ) occurred only on number of leaves and leaf area of the cotton cv. 'BRS Topázio', at 108 DAS.

Based on the effect of salinity on stem diameter of the cotton cv. 'BRS Topázio' at 53 and 108 DAS (Figure 1A), there were decreases of 3.56 and $4.50 \%$ per unit increase in water salinity. Comparing the plants irrigated using water with low and high salinity, the reductions were 16.92 and $22.15 \%$, corresponding to 0.95 and $1.75 \mathrm{~mm}$, respectively.

Plant height decreased with the increase of salinity (Figure $1 B$ ), regardless of the K doses; however, the level of this effect varied according to the evaluated interval, so that within the interval between 1.5 and $6.0 \mathrm{dS} \mathrm{m}^{-1}$, there were percent losses of the order of $31.93 \%(13.60 \mathrm{~cm})$ at 53 DAS and $46.34 \%(30.01 \mathrm{~cm})$ at 108 DAS, i.e., reductions of 6.41 and $8.92 \%$ per unit increase in the irrigation water salinity, at 53 and 108 DAS, respectively.

Both variables exhibited linear reduction with the increment of salinity, which may be related to the decrease in the osmotic potential, which compromises the transport of water towards plant cells (Ahmed \& Moritani, 2010). Oliveira et al. (2008), working with cotton cultivars irrigated using water with different salinity levels $\left(0.5\right.$ to $\left.8.5 \mathrm{dS} \mathrm{m}^{-1}\right)$ in the period from 21 to 56 days after planting, also observed that the growth of the three cultivars was inhibited by the increment in the saline concentration in the irrigation water.

The increase in irrigation water salinity also significantly reduced the number of leaves and leaf area of the cotton cv. 'BRS Topázio' at 53 DAS (Figures 1C and 1D), with a progressive reduction in $\mathrm{NL}$ (8.68 leaves) and LA $\left(336.19 \mathrm{~cm}^{2}\right)$ as the electrical conductivity of the irrigation water increased from 1.5 to $6.0 \mathrm{dS} \mathrm{m}^{-1}$, respectively. With these reductions of 9.56 and $10.58 \%$ in the number of leaves and leaf area per unit increase of $\mathrm{ECW}$, this phenomenon contributes to reducing the capacity of production of organic assimilates and results in the inhibition of cotton growth, as also reported by Oliveira et al. (2012).

Table 1. Summary of the analysis of variance for stem diameter (SD), plant height (PH), number of leaves (NL) and leaf area (LA) of the cotton cv. 'BRS Topázio' irrigated with water of different saline levels and potassium doses, at 53 and 108 days after sowing

\begin{tabular}{|c|c|c|c|c|c|c|c|c|c|}
\hline \multirow{4}{*}{ Source of variation } & \multirow{4}{*}{ DF } & \multicolumn{8}{|c|}{ Mean squares } \\
\hline & & \multicolumn{2}{|c|}{ SD } & \multicolumn{2}{|c|}{$\overline{\mathrm{PH}}$} & \multicolumn{2}{|c|}{$\mathrm{NL}$} & \multicolumn{2}{|c|}{ LA } \\
\hline & & \multicolumn{8}{|c|}{ Days after sowing } \\
\hline & & 53 & 108 & 53 & 108 & 53 & 108 & 53 & 108 \\
\hline Saline levels (SL) & 3 & $2.18^{\star \star}$ & $7.28^{\star \star}$ & $422.81^{\star \star}$ & $2026.13^{* *}$ & $171.02^{\star \star}$ & $553.57^{\star \star}$ & $268992.6^{\star \star}$ & $2610788.3^{* *}$ \\
\hline Linear regression & 1 & $6.07^{\star \star}$ & $32.07^{* *}$ & $1233.97^{* *}$ & $6010.0^{\star \star}$ & $504.60^{\star *}$ & $1535.2^{\star *}$ & $753610.23^{* *}$ & $7583664.7^{* \star}$ \\
\hline Quadratic regression & 1 & $0.46^{\mathrm{ns}}$ & $1.45^{\text {ns }}$ & $34.34^{\text {ns }}$ & $15.19^{\text {ns }}$ & $8.33^{\text {ns }}$ & $111 .-2^{\text {ns }}$ & $52830.5^{\mathrm{ns}}$ & $75862.9^{\text {ns }}$ \\
\hline $\mathrm{K}$ doses (KD) & 3 & $0.09^{\text {ns }}$ & $0.25^{\mathrm{ns}}$ & $58.64^{\text {ns }}$ & $174.17^{\text {ns }}$ & $11.42^{\text {ns }}$ & $31.07^{\mathrm{ns}}$ & $27845.1^{\text {ns }}$ & $108968.8^{\text {ns }}$ \\
\hline Linear regression & 1 & $0.19^{\text {ns }}$ & $015^{\text {ns }}$ & $146.64^{\star \star}$ & $440.10^{\star *}$ & $1.06^{\mathrm{ns}}$ & $90.04^{\text {ns }}$ & $65055.8^{*}$ & $310319.7^{\text {ns }}$ \\
\hline Quadratic regression & 1 & $0.05^{\text {ns }}$ & $0.21^{\mathrm{ns}}$ & $0.44^{\mathrm{ns}}$ & $0.75^{\text {ns }}$ & $5.33^{\text {ns }}$ & $1.69^{\text {ns }}$ & $15063.4^{\mathrm{ns}}$ & $16387.7^{\mathrm{ns}}$ \\
\hline Interaction SL*KD & 9 & $0.16^{\text {ns }}$ & $0.65^{\text {ns }}$ & $17.04^{\mathrm{ns}}$ & $82.02^{\text {ns }}$ & $4.86^{\mathrm{ns}}$ & $209.15^{\star \star}$ & $21178.74^{\text {ns }}$ & $300370.1^{\star \star}$ \\
\hline Blocks & 2 & $0.18^{\text {ns }}$ & $0.21^{\mathrm{ns}}$ & 54.84 & $0.91^{\text {ns }}$ & $7.64^{\mathrm{ns}}$ & $65.81^{\text {ns }}$ & $18717.0^{\text {ns }}$ & $7177.05^{\mathrm{ns}}$ \\
\hline Residual & 30 & 0.18 & 0.64 & 23.17 & 52.16 & 4.17 & 52.21 & 14588.2 & 91697.8 \\
\hline CV (\%) & & 8.34 & 11.37 & 13.45 & 14.51 & 15.78 & 16.46 & 18.38 & 10.44 \\
\hline
\end{tabular}

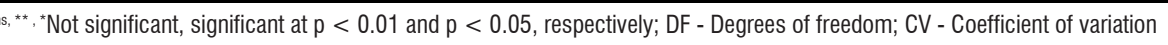



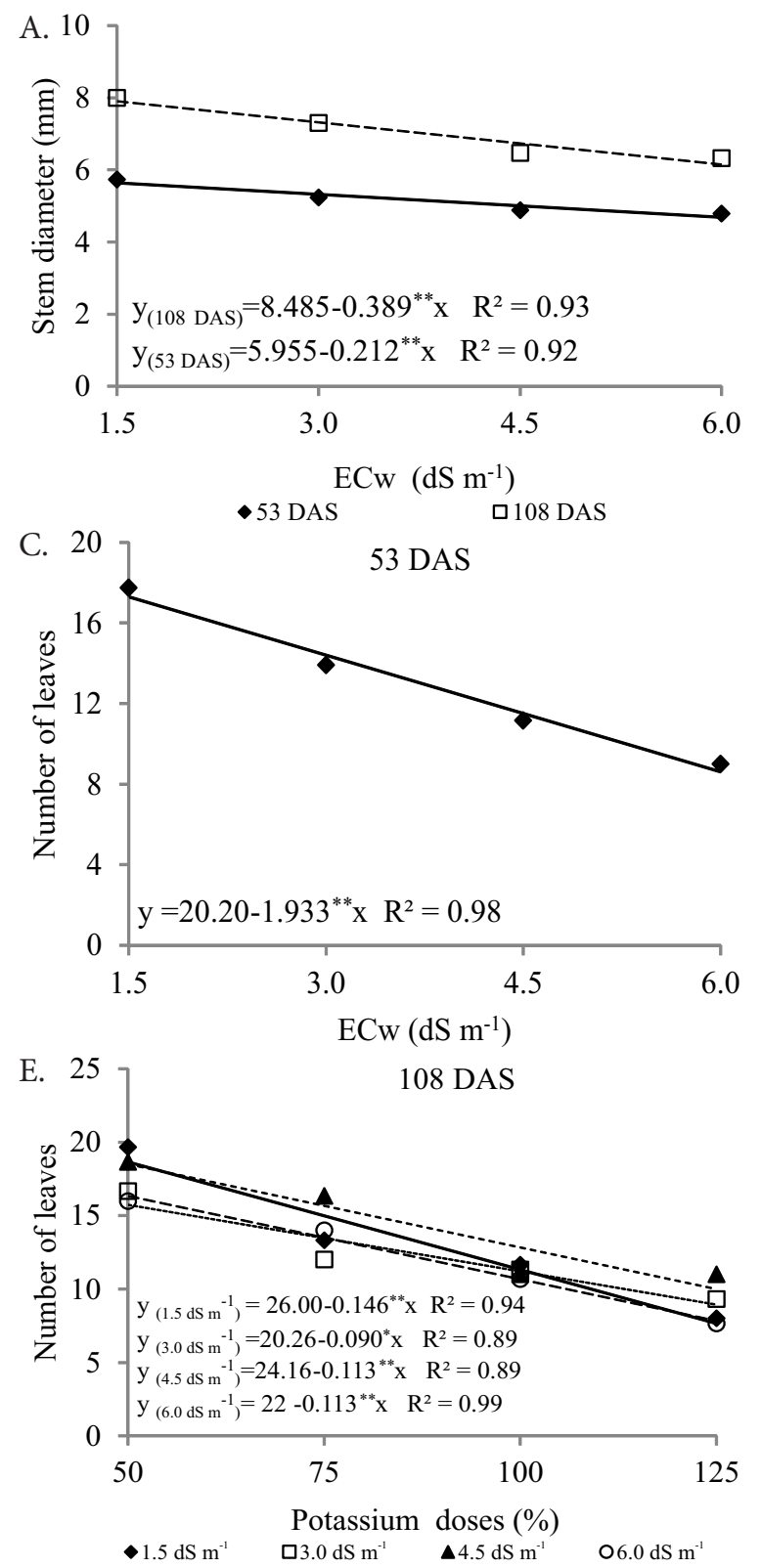
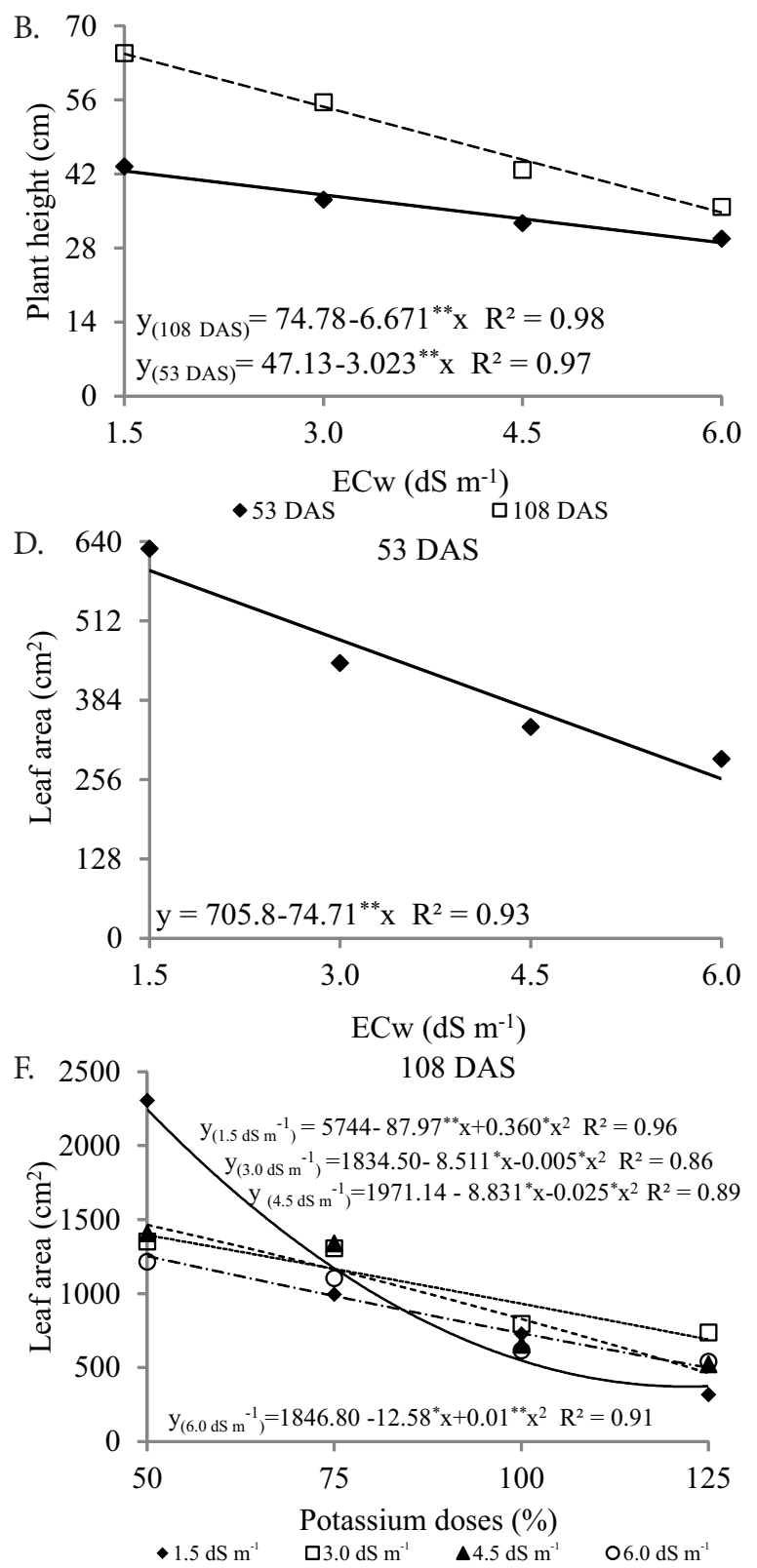

Figure 1. Stem diameter (A), plant height (B) at 53 and 108 days after sowing - DAS, number of leaves (C) and leaf area (D) at 53 DAS, as a function of the water electrical conductivity - ECW, and number of leaves (E) and leaf area (F) of the cotton cv. 'BRS Topázio', as a function of the interaction between the factors ECw levels and potassium doses, at 108 DAS

The interaction between $\mathrm{K}$ doses and the different saline levels of irrigation water caused reductions in the number of leaves at 108 DAS; however, the intensification of the effects depended on irrigation water salinity (Figure $1 \mathrm{E}$ ). The $\mathrm{K}$ dose resulting in highest $\mathrm{NL}$ was $50 \% \mathrm{~K}_{2} \mathrm{O}$, associated with water salinity of 1.5

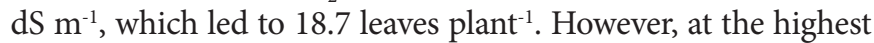
$\mathrm{K}$ dose $\left(125 \% \mathrm{~K}_{2} \mathrm{O}\right)$, the number of leaves showed reductions of $58.55,42.82,45.78$ and $51.86 \%$ in plants irrigated with water of $1.5,3.0,4.5$ and $6.0 \mathrm{dS} \mathrm{m} \mathrm{m}^{-1}$, respectively, compared with the lowest dose of $\mathrm{K}$ fertilization. The negative effects of the high $\mathrm{K}$ doses on plants subjected to salt stress, evidenced in the present study, are similar to those observed in sorghum plants, because the addition of potassium chloride, a salt with high saline index, results in intensification of the osmotic effect (Lacerda et al., 2003).

Regarding cotton leaf area as a function of the interaction between factors (SL $x$ KD) at 108 DAS (Figure 1F), in consonance with the results obtained for number of leaves, plants irrigated with ECw of $1.5 \mathrm{dS} \mathrm{m}^{-1}$ and fertilized with $50 \% \mathrm{~K}_{2} \mathrm{O}$ showed greater leaf expansion $\left(2245.5 \mathrm{~cm}^{2}\right)$. However, as the $\mathrm{K}$ doses increased to $125 \% \mathrm{~K}_{2} \mathrm{O}$, there were reductions of $83.41,50.40$, 67.51 and $65.35 \%$ at ECw levels of 1.5, 3.0, 4.5 and $6.0 \mathrm{dS} \mathrm{m}^{-1}$, with reductions in leaf expansion of 1873, 703.95, 990.45 and $812.25 \mathrm{~cm}^{2}$, respectively, compared with plants that received the dose of $50 \% \mathrm{~K}_{2} \mathrm{O}$.

Growth reductions caused by the increase in $\mathrm{K}$ fertilization were also reported by Prazeres et al. (2015), who evaluated growth and physiology of two cowpea cultivars irrigated with saline water and subjected to different $\mathrm{K}$ levels in the form of $\mathrm{KCl}$ $(0.5 ; 1.0 ; 2.0$ and $4.0 \mathrm{~g} \mathrm{KCl}$ per pot), and observed that the highest $\mathrm{K}$ doses associated with salinity caused a deleterious effect on the growth of the cowpea cultivars. However, the results differ from those reported by Gurgel et al. (2010), who highlighted the benefit of K fertilization in melon plants, cv. Goldex, under salt stress, but using potassium sulfate.

Based on the analysis of variance (Table 2), significant effect occurred only for irrigation water salinity on flower abortion rate 
Table 2. Summary of the analysis of variance for flower abortion rate (FAR), total number of bolls (TNB) and seed weight (CSW) of the cotton cv. 'BRS Topázio' irrigated with water of different saline levels and potassium doses

\begin{tabular}{lcccc}
\hline \multirow{2}{*}{ Source of variation } & \multirow{2}{*}{ DF } & \multicolumn{3}{c}{ Mean squares } \\
\cline { 3 - 5 } Saline levels (SL) & 3 & $1106.43^{*}$ & $108.40^{* *}$ & $1625.09^{* *}$ \\
Linear regression & 1 & $3125.24^{* \star}$ & $315.10^{* *}$ & $4752.51^{\text {** }}$ \\
Quadratic regression & 1 & $0.94^{\text {ns }}$ & $9.18^{\text {ns }}$ & $16.67^{\text {ns }}$ \\
Doses of K (KD) & 3 & $396.48^{\text {ns }}$ & $2.52^{\text {ns }}$ & $12.45^{\text {ns }}$ \\
Linear regression & 1 & $0.07^{\text {ns }}$ & $0.20^{\text {ns }}$ & $10.74^{\text {ns }}$ \\
Quadratic regression & 1 & $737.27^{\text {ns }}$ & $1.02^{\text {ns }}$ & $13.85^{\text {ns }}$ \\
Interaction SL x KD & 9 & $449.33^{\text {ns }}$ & $5.96^{\text {ns }}$ & $11.51^{\text {ns }}$ \\
Blocks & 2 & $337.75^{\text {ns }}$ & $2.14^{\text {ns }}$ & $5.14^{\text {ns }}$ \\
Residual & 30 & 260.26 & 3.12 & 26.08 \\
CV (\%) & & 14.58 & 18.29 & 17.32 \\
\hline
\end{tabular}

ns, ${ }^{* *},{ }^{*}$ Not significant, significant at $p<0.01$ and $p<0.05$, respectively; DF - Degrees of freedom; CV - Coefficient of variation

(FAR), total number of bolls (TNB) and seed weight (CSW) of the cotton cv. 'BRS Topázio', although there was no significant influence $(\mathrm{p}>0.05)$ for the interaction between irrigation water salinity and $\mathrm{K}$ doses on any of the analysed variables.

Irrigation with saline water caused a linear increment in the flower abortion rate (FAR) of the cotton cv. 'BRS Topázio', equal to $16.81 \%$ per unit increase in $\mathrm{ECW}$, and the highest values were estimated for plants irrigated using water of highest salinity level $\left(6.0 \mathrm{dS} \mathrm{m}^{-1}\right)$, of $57.47 \%$, corresponding to an increment of $56.85 \%$ in comparison to plants irrigated using water with the lowest saline level $\left(1.5 \mathrm{dS} \mathrm{m}^{-1}\right)$, with $35.82 \%$ in FAR (Figure 2A). It is worth pointing out that the excess of salts in the root zone of the plants also has harmful effects on flowering, due to the greater osmotic effect outside the roots and restriction to water flow from soil to plants. In addition, high saline concentration in the soil can cause imbalances induced by the toxicity of $\mathrm{Na}^{+}$ and $\mathrm{Cl}^{-}$ions, interfering with the hormonal balance and leading to alterations in the microsporogenesis and stamen filament elongation, resulting in programed cell death in some types of tissues, ovule abortion and senescence of fertilized embryos (Shrivastava \& Kumar, 2015).

The results of total number of bolls are consistent with those observed for flower abortion rate, with reductions in response to the increase in irrigation water salinity. There was reduction of $12.83 \%$ per unit increase in salinity and total loss of 6.42 bolls plant $^{-1}(71.51 \%)$ in plants irrigated ECw of $6.0 \mathrm{dS} \mathrm{m}^{-1}$, compared with those irrigated using water of lowest salinity (Figure 2B). These results agree with those obtained by Oliveira et al. (2012), who worked with the cultivar Delta Opal, under irrigation with salinized water, and observed that the number of bolls per plant decreased by $6.46 \%$ per unit increase in salinity.

According to the regression equation (Figure 2C), there was a decreasing linear effect of the ECw levels on cotton seed weight (CSW), with reduction of $14.99 \%$ per unit increase in ECw, i.e., plants that received the highest saline level $\left(6.0 \mathrm{dS} \mathrm{m}^{-1}\right)$ exhibited a reduction in this variable of $87.04 \%\left(26.69 \mathrm{~g} \mathrm{plant}^{-1}\right)$, compared with those irrigated with ECw of $1.5 \mathrm{dS} \mathrm{m}^{-1}$. The reduction in cotton seed weight due to the increase in ECw can be attributed to the reduction in the osmotic potential and metabolic disorders, especially related to the absorption of
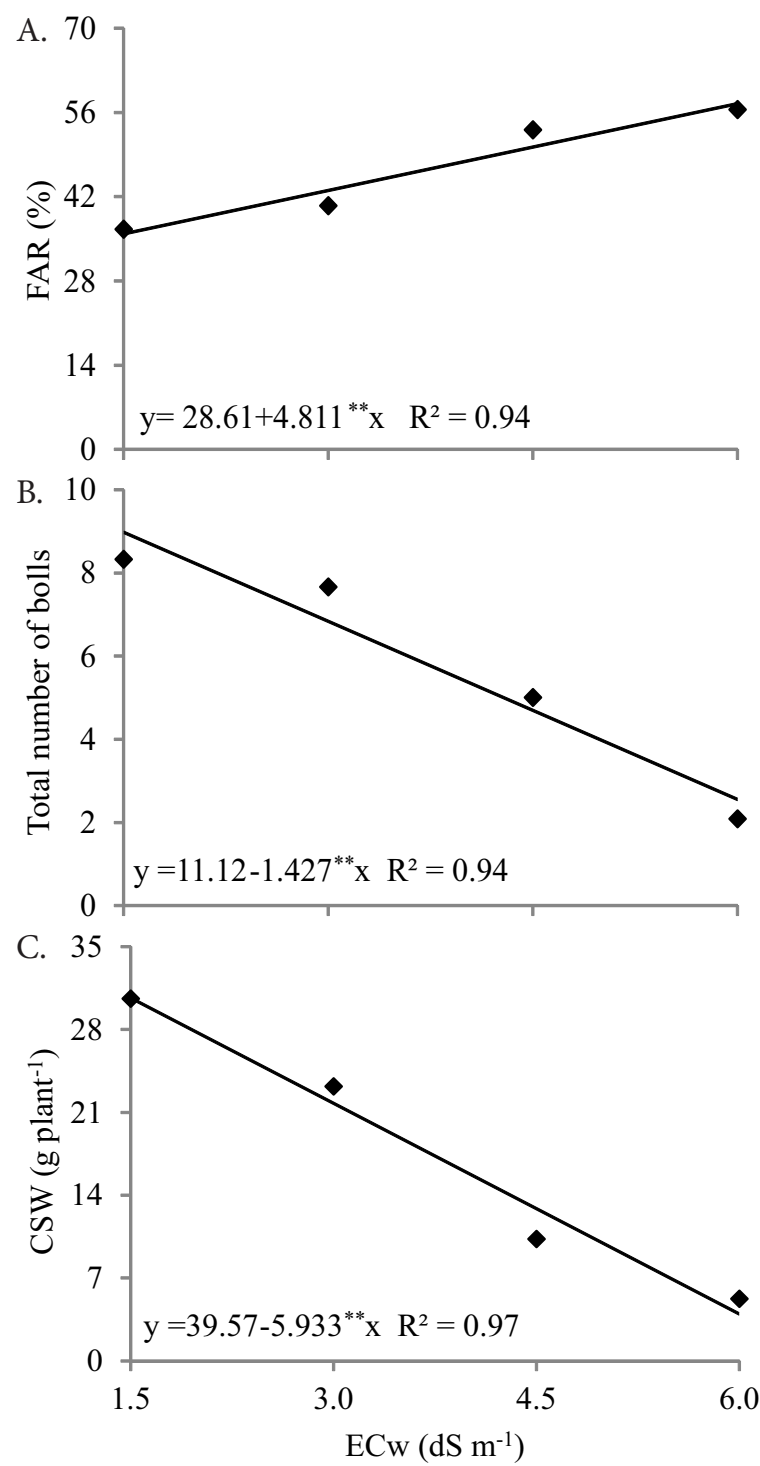

Figure 2. Flower abortion rate - FAR (A), total number of bolls - TNB (B) and cotton seed weight - CSW (C) of the cotton cv. 'BRS Topázio', as a function of water electrical conductivity - ECW

water and nutrients by plants, resulting in lower number of bolls and, consequently, reductions in cotton production (Cordão Sobrinho et al., 2007; Oliveira et al., 2012). Santos et al. (2016), working with the cotton cv. 'BRS Topázio', under irrigation water salinity, also observed reduction in cotton production of $80.5 \%$ between plants irrigated using water of 0.7 and $8.7 \mathrm{dS} \mathrm{m}^{-1}$.

\section{Conclusions}

1. Irrigation water salinity reduces stem diameter, plant height, number of leaves and leaf area of the cotton cv. 'BRS Topázio', and leaf area at 53 days after sowing (DAS) was the most affected variable.

2. The highest $\mathrm{K}$ doses associated with the increase in irrigation water salinity led to a more deleterious effect on number of leaves and leaf area at 108 DAS.

3. Progressive increments in irrigation water salinity caused a proportional increase in flower abortion rate and, consequently, reduced the total number of bolls and cotton seed weight. 


\section{Literature Cited}

Ahmed, B. A. O.; Inoue, M.; Moritani, S. Effect of saline water irrigation and manure application on the available water content, soil salinity, and growth of wheat. Agricultural Water Management, v.97, p.165170, 2010. https://doi.org/10.1016/j.agwat.2009.09.001

Alves, L. R. A.; Barros, G. S. de C.; Bacchi, M. R. P. Produção e exportação de algodão: Efeitos de choques de oferta e de demanda. Revista Brasileira de Economia, v.62, p.381-405, 2008. https://doi. org/10.1590/S0034-71402008000400002

Ayers, R. S.; Westcot, D. W. A qualidade da água na agricultura. Campina Grande: Universidade Federal da Paraíba, 1999. 153p. Estudos FAO: Irrigação e drenagem, 29

Cardoso, G. D.; Alves, P. L. da C. A.; Beltrão, N. E. de M.; Vale, L. S. do. Períodos de interferência das plantas daninhas em algodoeiro de fibra colorida BRS Safira. Revista Ciência Agronômica, v.41, p.456462, 2010. https://doi.org/10.1590/S1806-66902010000300019

Cavalcante, L. F.; Vieira, M. da Silva; Santos, A. F. dos; Oliveira, W. M. de; Nascimento, J. A. M. do. Água salina e esterco bovino líquido na formação de mudas de goiabeira cultivar paluma. Revista Brasileira de Fruticultura, v.32, p.251-261, 2010. https://doi.org/10.1590/ S0100-29452010005000037

Claessen, M. E. C. Manual de métodos de análise de solo. 2.ed. rev. atual. Rio de Janeiro: Embrapa CNPS, 1997. 212p. Documentos, 1

Cordão Sobrinho, F. P.; Fernandes, P. D.; Beltrão, N. E. de M.; Soares, F. A. L.; Terceiro Neto, C. P. C. Crescimento e rendimento do algodoeiro BRS-200 com aplicações de cloreto de mepiquat e lâminas de irrigação. Revista Brasileira de Engenharia Agrícola e Ambiental, v.11, p.284-292, 2007.https://doi.org/10.1590/S1415-43662007000300007

EMBRAPA - Empresa Brasileira de Pesquisa Agropecuária. Centro Nacional de Pesquisa de Algodão. Algodão colorido: “Tecnologia Embrapa para a geração de emprego e renda na agricultura familiar do Brasil". Campina Grande: Embrapa CNPA, 2011. 2p. Circular Técnica, 17

Ferreira, D. F. Sisvar: A computer statistical analysis system. Ciência e Agrotecnologia, v.35, p.1039-1042. 2011. https://doi.org/10.1590/ S1413-70542011000600001

Grimes, D. W.; Carter, L. M. A linear rule for direct nondestructive leaf area measurements. Agronomy Journal, v.3, p.477-479, 1969. https://doi.org/10.2134/agronj1969.00021962006100030048x

Gurgel, M. T.; Gheyi, H. R.; Oliveira, F. H. T. de. Acúmulo de matéria seca e nutrientes em meloeiro produzido sob estresse salino e doses de potássio. Revista Ciência Agronômica, v.41, p.18-28, 2010.

Khan, M. H.; Panda, S. K. Alterations in root lipid peroxidation and antioxidative responses in two rice cultivars under $\mathrm{NaCl}$ - salinity stress. Acta Physiologiae Plantarum, v.30, p.81-89, 2008. https:// doi.org/10.1007/s11738-007-0093-7
Lacerda, C. F. de; Oliveira, H. de P. M. de; Oliveira, T. S. de; Gomes Filho, E. Crescimento e acúmulo de íons em folhas de sorgo forrageiro submetido a soluções iso-osmóticas de sais $(\mathrm{NaCl}+\mathrm{KCl})$. Revista Ciência Agronômica, v.34, p.1-6, 2003.

Langer, K.; Levchenko, V.; Fromm, J.; Geiger, D.; Steinmeyer, R.; Lautner, S.; Ache, P.; Hedrich, R. The poplar $\mathrm{K}^{+}$channel KPT1 is associated with $\mathrm{K}^{+}$uptake during stomatal opening and bud development. The Plant Journal, v.37, p.828-838, 2004. https://doi.org/10.1111/j.09607412.2003.02008.x

Neves, A. L. R.; Guimarães, F. V. A.; Lacerda, C. F. de; Silva, F. B. da; Silva, F. L. B. da. Tamanho e composição mineral de sementes de feijãode-corda irrigado com água salina. Revista Ciência Agronômica, v.39, p.569-574, 2008.

Novais, R. F; Neves, J. C. L.; Barros, N. F. Ensaio em ambiente controlado. In: Oliveira, A.J. (ed.) Métodos de pesquisa em fertilidade do solo. Brasília: EMBRAPA-SEA, 1991. p.189-253.

Oliveira, A. M. de; Oliveira, A. M. P. de; Dias, N. da S.; Medeiros, J. F. de. Irrigação com água salina no crescimento inicial de três cultivares de algodão. Irriga, v.13, p.467-475, 2008.

Oliveira, F. de A. de; Medeiros, J. F. de; Oliveira, F. R. A. de; Freire, A. G.; Soares, L. C. da S. Produção do algodoeiro em função da salinidade e tratamento de sementes com regulador de crescimento. Revista Ciência Agronômica, v.43, p.279-287, 2012. https://doi.org/10.1590/ S1806-66902012000200010

Prazeres, S. da S.; Lacerda, C. F. de; Barbosa, F. E. L.; Amorim, A. V.; Araújo, I. C. da S.; Cavalcante, L. F. Crescimento e trocas gasosas de plantas de feijão-caupi sob irrigação salina e doses de potássio. Revista Agro@mbiente, v.9, p.111-118, 2015.

Richards, L.A. Diagnosis and improvement of saline and alkali soils. Washington: U.S. Department of Agriculture, 1954. 160p. Agriculture Handbook, 60.

Santos, J. B. dos; Gheyi, H. R.; Lima, G. S. de; Xavier, D. A.; Cavalcante, L. F.; Centeno, C. R. M. Morfofisiologia e produção do algodoeiro herbáceo irrigado com águas salinas e adubado com nitrogênio. Comunicata Scientiae, v.7, p.86-96, 2016. https://doi.org/10.14295/ cs.v7i1.1158

Shimazaki, K.; Doi, M.; Assmann, S.M.; Kinoshita, T. Light regulation of stomatal movement. Annual Review of Plant Biology, v.58, p.219-247, 2007. https://doi.org/10.1146/annurev. arplant.57.032905.105434

Shrivastava, P.; Kumar, R. Salinidade do solo: Um problema ambiental sério e bactérias promotoras do crescimento das plantas como uma das ferramentas para seu alívio. Saudi Journal of Biological Sciences, v.22, p.123-131, 2015. https://doi.org/10.1016/j.sjbs.2014.12.001 